\title{
Василь Васильович ГоЙ
}

\author{
аспірант \\ кафедра економічного консалтингу, \\ Харківський національний економічний університет імені С. Кузнеця \\ E-mail: vasssgoi@gmail.com

\section{ІНТЕГРАЛЬНИЙ ПОКАЗНИК ЙМОВІРНОСТІ БАНКРУТСТВА КОРПОРАТИВНИХ ПІДПРИЄМСТВ}

Гой, В. В. Інтегральний показник ймовірності банкрутства корпоративних підприємств [Текст] / Василь Васильович Гой // Економічний аналіз: зб. наук. праць / Тернопільський національний економічний університет; редкол.: О. В. Ярощук (голов. ред.) та ін. - Тернопіль: Видавничо-поліграфічний центр Тернопільського національного економічного університету «Економічна думка», 2017. - Том 27. - № 3. C. 182-189. - ISSN 1993-0259.

\section{Анотація}

Bступ. Із зростанням корпоративного сектору економіки виникає необхідність розробки аналітичного інструментарію, вирішення методологічних і практичних проблем, пов'язаних з аналізом і моніторингом ймовірності банкрутства корпоративних підприємств.

Мета. Метою дослідження $\epsilon$ вивчення можливостей застосування наявних економіко-математичних моделей, заснованих на теорії нечіткої логіки, для дослідження ймовірності банкрутства корпоративних підприємств.

Метод (методологія). Теоретичною та методологічною основою роботи слугують роботи провідних вітчизняних та зарубіжних фахівців у галузі антикризового управління підприємствами, зокрема діагностики ймовірності банкрутства. У ході дослідження були використані загальнонаукові знання 3 економічного аналізу, структурно-динамічного та експертного аналізу.

Результати. Розкрито переваги і можливості теорії нечіткої логіки стосовно аналізу ймовірності банкрутства підприємств та обгрунтовано доцільність застосування цього економіко-математичного апарату для аналізу фінансової стійкості та ймовірності банкрутства корпоративних підприємств. Для характеристики ймовірності банкрутства корпоративних підприємств запропоновано використовувати інтегральний показник, що базується на теорії нечіткої логіки. Зроблено висновок про те, що методи нечіткої логіки дозволяють здійснювати аналіз ймовірності банкрутства корпоративних підприємств в умовах невизначеності, наприклад, в тих випадках, коли статистичні дані для аналізу обмежені, або коли до переліку показників, які досліджуються, необхідно залучати якісні дані. Моделі, побудовані на нечіткій логіці, дозволяють не тільки аналізувати поточну ймовірність банкрутства корпоративного підприємства, але і прогнозувати його майбутній стан.

Ключові слова: корпоративне підприємство; ймовірність банкрутства; фактори банкрутства; якісні показники; кількісні показники; інтегральний показник ймовірності банкрутства; нечітка логіка.

\section{Vasyl Vasylyovych GOI}

$\mathrm{PhD}$ Student,

Department of Economic Consulting,

Simon Kuznets Kharkiv National Economic University

E-mail: vasssgoi@gmail.com

\section{INTEGRATED INDICATOR OF THE POSSIBILITY OF BANKRUPTCY OF CORPORATE ENTERPRISES}

\begin{abstract}
Introduction. With the growth of the corporate sector of the economy, it is necessary to develop analytical tools, solve methodological and practical problems related to the analysis and monitoring of the probability of bankruptcy of corporate enterprises.

Goal. The article aims to study the possibilities of using existing economic and mathematical models on the basis of the theory of fuzzy logic to investigate the probability of bankruptcy of corporate enterprises.
\end{abstract}

(C) Василь Васильович Гой, 2017 
Method (methodology). The works of leading domestic and foreign experts in the field of crisis management of enterprises, in particular, the diagnosis of the probability of bankruptcy have become the theoretical and methodological basis of the work. In the course of the study, general knowledge on economic analysis, structural and dynamic and expert analysis has been used.

Results. The advantages and possibilities of the theory of fuzzy logic concerning the analysis of the probability of bankruptcy of enterprises have been revealed. The expediency of application of this economic and mathematical device for the analysis of financial stability and probability of bankruptcy of corporate enterprises has been substantiated. To characterize the probability of bankruptcy of corporate enterprises, it is suggested to use an integral indicator based on the theory of fuzzy logic. It is concluded that fuzzy logic methods allow analyzing the probability of bankruptcy of corporate enterprises under uncertainty, for example, in cases where statistical data for analysis are limited, or when qualitative data is to be included in the list of indicators under investigation. Models, which are built on basis of fuzzy logic, allow to analyze the current probability of bankruptcy of a corporate enterprise and to predict its future state.

Keywords: corporate enterprise; probability of bankruptcy; bankruptcy factors; qualitative indicators; quantitative indicators; integral probability of bankruptcy; fuzzy logic

\section{JEL classification: C43, C49, G33, M41}

\section{Вступ}

Ринкова економіка виробила велику систему методів діагностики і прогнозування кризового фінансового стану підприємств, які дозволяють визначати загрозу банкрутства на ранніх стадіях і використовувати всі можливості для i нейтралізації. Проте проблема загального моніторингу фінансового стану корпоративного підприємства, спрямованого на дослідження індикаторів кризового розвитку і зниження загрози банкрутства, не перестає бути актуальною. Складність і багатовимірність завдань, які необхідно вирішувати антикризовим менеджерам, вимагають коректного обліку багатоаспектності процесів формування фінансового стану підприємства. Виникає потреба в розвитку і вдосконаленні теоретико-методичних підходів до діагностики фінансової кризи та аналізу можливих кризових ситуацій на рівні суб'єкта господарювання.

Усе вищевикладене підтверджує необхідність та затребуваність нашого дослідження, спрямованого на вдосконалення методичних і практичних основ діагностики кризового фінансового стану як сучасного методу інформаційно-аналітичного забезпечення антикризового менеджменту на рівні підприємства.

Питаннями вдосконалення методів діагностики в процесі антикризового управління підприємством цікавилися такі вітчизняні та іноземні вчені: Е. Альтман, І. Ансофф, К. Беєрман, У. Бівер, І. Бланк, Є. Бойко, М. Кизим, В. Кошкін, Л. Лігоненко, Т. Петерс, Т. Таффлер, О. Терещенко, Е. Уткін, I. Фаріон та ін. Однак особливості функціонування підприємств вони розглядають лише при настанні кризи та/або під час виходу з неї, ігноруючи при цьому превентивну складову системи антикризового управління.

Слід зазначити, що у більшості цих робіт розглядаються лише окремі аспекти діагностики, яку часто визначають лише як напрямок економічного аналізу, що значно зменшує її значення та обмежує сферу застосування.

Як показує практика, дотепер не існує досконалої методології та універсальних методик застосування економічних та управлінських інструментів, що дозволили б менеджерам проводити діагностику та оцінити стан підприємства за значенням зведеного (інтегрального) показника та здійснювати антикризову стабілізацію поточного стану і прогнозування можливих майбутніх наслідків діяльності корпоративних підприємств.

\section{Мета статті}

Метою дослідження $є$ вивчення можливостей застосування чинних економіко-математичних моделей, заснованих на теорії нечіткої логіки, для дослідження ймовірності банкрутства корпоративних підприємств.

\section{Виклад основного матеріалу дослідження}

У практиці фінансового аналізу дуже добре відома низка показників, що характеризують окремі сторони поточного фінансового становища підприємства. Сюди належать показники ліквідності, рентабельності, стійкості, оборотності капіталу, прибутковості і т. д. Щодо окремих показників, то відомі нормативи, що характеризують їх значення позитивно чи негативно. Наприклад, коли власні кошти підприємства перевищують половину всіх його пасивів, то коефіцієнт автономії відповідно більше 0,5 , а це значення «добре» (відповідно, значення менше 0,5 - «погано»). Але в більшості випадків показники, 
які оцінюються при аналізі, однозначно нормувати неможливо. Це пов'язано зі специфікою галузей економіки, з поточними особливостями діючих підприємств, зі станом економічного середовища, в якому вони працюють.

Ймовірність виступає одним 3 найбільш часто вживаних показників ризику фінансової неспроможності. Вірогідність банкрутства оцінюється за допомогою прогнозів розвитку бізнесу (прогнозів можливого банкрутства) і може бути виражена формалізовано (у відсотках або в частках одиниці) або неформалізовано (наприклад, «висока» або «низька», «надмірна» або «помірна»). Ймовірність банкрутства підприємства існує завжди, оскільки, як мінімум, не можна абстрагуватися від обставин непереборної сили. Проте банкрутство вважається малоймовірним явищем [1] та відносно рідко зустрічається в корпоративній практиці.

Проте будь-яку зацікавлену становищем підприємства особу чи сторону (дальше зацікавлена особа) не завжди задовольнить проста кількісна оцінка показників. У такому випадку важливо знати, чи прийнятні отримані значення, чи інформативні вони та якою мірою. Крім того, зацікавлена особа прагне встановити логічний зв'язок кількісних значень показників виокремленої групи із ймовірністю (ризиком) банкрутства. Зазвичай бінарної оцінки «добре - погано» замало, оскільки користувача інформацією цікавлять відтінки ситуації і економічна інтерпретація відтінків значень. Завдання ускладнюється ще й тим, що показників багато, змінюються вони часто різноспрямовано, а відповідно користувач інформацією прагне «згорнути» набір всіх показників в один комплексний, за значенням якого можна судити про ймовірність (ризик) банкрутства.

Прогнозування ймовірності банкрутства, як правило, здійснюється на основі системи показників, певні значення, наявність або відсутність яких $€$ його прямими (сутнісними) або непрямими (емпіричними) ознаками.

3 урахуванням базових показників, які застосовуються з метою прогнозування ймовірності банкрутства, на нашу думку, слід розмежувати фінансовий і комплексний методичні підходи до оцінки фінансової стабільності. Фінансовий підхід дозволяє оцінити рівень фінансової стабільності за фінансовими показниками діяльності підприємства. Такий підхід може бути реалізований у межах облікових, ринкових або змішаних методів. Облікові методи здебільшого апелюють до показників фінансової звітності, вони більш популярні і широко представлені, оскільки затребувані зовнішніми аналітиками, а також можуть застосовуватися як щодо публічних компаній, так і стосовно підприємств, що не мають публічного статусу. Ринкові методи, орієнтовані на корпоративних емітентів, засновані на припущенні про те, що фондовий ринок найбільш ефективно відображає фінансовий стан публічної компанії. Пріоритетного значення у зв'язку з цим набувають такі базові показники оцінки фінансової стабільності, як ринкова капіталізація, ринкова вартість боргу, сукупна ринкова вартість компанії та ін. Змішані фінансові методи поєднують облікові і ринкові показники функціонування бізнесу. Прикладом моделі, побудованої змішаним методом, виступає Z-рахунок Е. Альтмана (1968 р.). Ця модель заснована переважно на показниках фінансової звітності, але додатково вимагає відомостей і про ринкову капіталізацію. Вважається, що саме змішані моделі мають найбільш високий рівень прогнозного потенціалу [2]. Комплексний підхід не обмежується фінансовими характеристиками функціонування підприємств. У межах реалізації цього підходу можуть враховуватися окремі зовнішні і (або) внутрішні умови бізнесу, в тому числі неекономічні [3].

За видом прогнозної моделі всі методичні підходи можна поділити на багатоваріантні - вони засновані на системі показників та не передбачають побудови зведеного показника фінансової стабільності, та одноваріантні - тобто ті, які дозволяють оцінити фінансовий стан підприємства за значенням зведеного (інтегрального) показника. Зазначена класифікація справедлива як для комплексних, так і для фінансових методів діагностування ймовірності банкрутства. Більшість відомих фінансових моделей є одноваріантними, це, зокрема, регресійні моделі (дискримінантні та моделі бінарного вибору). Усі фінансові моделі, як правило, будуються методом традиційного коефіцієнтного аналізу. Комплексні моделі, навпаки, найчастіше $\epsilon$ багатоваріантними та представляють собою систему показників і не передбачають оцінку рівня фінансової стабільності підприємства на основі зведеного показника. Очевидно, що і в цьому випадку можливе агрегування отриманих оцінок (висновків) 3 використанням формалізованого алгоритму. Наприклад, використовуються бальні (скорингові) комплексні моделі, коли кожному значенню, наявності або відсутності тієї чи іншої ознаки банкрутства присвоюється певний бал, а ймовірність банкрутства оцінюється за сумою балів у зіставленні з їі критичним значенням. Слід зазначити, що формування зведених показників здійснюється із застосуванням широкого діапазону методів, які активно використовуються в макроекономічному аналізі [4] і можуть бути адаптовані для цілей діагностики ймовірності банкрутства підприємств.

Будь-яке підприємство, 3 точки зору системного аналізу, слід розглядати як складноструктуровану систему, яка складається 3 неоднорідних компонентів та має зв'язки, що визначають їі просторово-часову структуру. Загалом таку систему можна охарактеризувати деякою кількістю її можливих станів, а також деякими можливостями їх реалізації, які, безперервно змінюючись 
в часі, визначають динамічні характеристики системи (підприємства) і її реакції на внутрішні процеси і зовнішні впливи. Вважатимемо, що простір можливих станів підприємства містить стани 1,2,...,D. Нехай стан 1 - це стан, коли загроза банкрутства протягом заданого періоду наближається до нуля, а стан D стан банкрутства. Усі інші проміжні стани розглядаються впорядкованими в тому сенсі, що зі збільшенням номера стану ймовірність банкрутства збільшується [5].

Кожний із станів можна описати сукупністю факторів як кількісного, так і якісного характеру. Чисельні значення кількісних факторів вимірюються за допомогою різних інструментальних засобів, а якісні фактори встановлюються експертним шляхом. При цьому кожний із факторів має власну область визначення. Кількісні фактори, як правило, задаються в шкалах типу абсолютної, відносної або інтервальної. Для якісних факторів область визначення вибирається в істотно більш слабких шкалах найменувань або порядкових шкалах.

Якщо, наприклад, взяти добре відомий метод Альтмана для оцінки ризику банкрутства корпорації, то виявиться, що коефіцієнти у формулі Альтмана змінюються кожного року та є різними для кожної країни, тобто для методу Альтмана не властива стійкість коливань вихідних даних. Недолік методу в тому, що з його використанням робляться висновки щодо однієї приватної корпорації на основі комплексу даних інших корпорацій, які оцінюються як статистичні дані. Таким чином, індивідуальні відмінності підприємства в процесі аналізу за методом Альтмана не беруться до уваги, нівелюються, при цьому висновки про ймовірність банкрутства підприємства робляться на ненадійній основі. Ця особливіть характерна і для інших добре відомих моделей визначення ймовірності банкрутства. У результаті цього аналітик чи особа, яка досліджує підприємство для прийняття рішення про ймовірність банкрутства, змушена або відмовитись від класичних ймовірнісних статитстичних методів, або додатково використовувати в аналізі експертні, мінімаксні та інші детермінантські підходи, які не в змозі враховувати невизначеність поведінки корпоративного підприємства як фінансової систем належним чином. Іноді в ході моделювання аналітики використовують суб'єктивні ймовірності, однак обгрунтованість уведення точкових ймовірнісних оцінок і суб'єктивних ймовірнісних розподілів у більшості моделей, які використовуються, досить суперечлива.

Тому розроблення принципово нової теорії управління фінансовими системами, що функціонують в умовах суттєвої невизначеності, набуло розвитку ще півстоліття тому та базується на теорії нечітких множин, фундаментальний внесок у яку належить Лотфі Заде [6]. Відповідно до основних положень теорії нечітких множин, якщо кожному елементу х ставиться у відповідність ступінь його приналежності нечіткій множині $B$, то ця приналежність виражається числом $\mu_{\mathrm{B}}(\mathrm{x})$ на інтервалі [0; 1 . Таке розширене поняття функції приналежності дозволяє гнучко формалізувати і досліджувати множину кількісних та якісних об'єктів, представляючи їх за допомогою нечітко формалізованої множини (нечіткої множини) [7].

Як зазначено вище, відображення ознаки на шкалу визначаться функцією приналежності. Для кількісних факторів така функція має вигляд індикаторної функції, тобто результат вимірювання хлежить на шкалі $B$ з імовірністю одиниця:

$$
\mu_{\mathrm{B}}(\mathrm{x})=\left\{\begin{array}{l}
1, \text { якщо } \mathrm{x} \in \mathrm{B} \\
0, \text { якщо } \mathrm{x} \notin \mathrm{B}
\end{array}\right.
$$

У випадку якісних факторів використовують функцію приналежності у вигляді числа з інтервалу [0; 1], тобто результат «вимірювання» експерта не $\epsilon$ однозначним.

Використання одночасно кількісних і якісних факторів для визначення ймовірності банкрутства із зазначеними функціями приналежності призводить до того, що кордони станів перетинаються. Це означає, що висновок про номер стану буде також неоднозначним. Водночас подібний підхід відповідає економіці зазначеного явища (наприклад, зміні ймовірності банкрутства підприємства), оскільки процес переходу з одного стану в інший є безперервним, що не дозволяє встановити чітку межу між його станами. Крім того, використання функції приналежності з інтервалу [0; l] для опису якісних факторів дозволяє певним чином формалізувати і таку інформацію. 3 точки зору теорії вимірювань, це дає можливість перейти до більш «сильної» шкали, зокрема в нашому випадку - до шкали інтервалів.

Оскільки кількісні фактори завжди можуть бути представлені в шкалі інтервалів, то використання функції приналежності дозволяє уніфікувати описання факторів ймовірності банкрутства в межах шкали інтервалів.

Таким чином, у результаті вектор ймовірності банкрутства, компонентами якого є кількісні і якісні фактори, виражається в єдиній вимірювальній шкалі.

Під функцією відгуку $Y$ розуміється значення ймовірності банкрутства, яка залежить від факторів-компонент вектора банкрутства. Ця функція називається узагальненим параметром оцінки ймовірності банкрутства.

Побудова такої функції забезпечує вирішення задачі з оцінки ймовірності банкрутства при зіставленні значення $Y$ з одним із станів $1,2, \ldots, \mathrm{D}$. 
Узагальнюючи сказане вище, зазначимо, що завдання розробки методу оцінки ймовірності банкрутства підприємства може містити:

- розробку системи критеріїв адекватності математичної моделі економічного стану об'єкта дослідження, що дозволить обгрунтувати достовірність отриманих результатів;

- $\quad$ розробку методу обробки кількісних і якісних факторів банкрутства підприємства, а також нечітких оцінок експертів, що дозволить знизити загальну похибку результатів дослідження;

- розробку математичної моделі оцінки ймовірності банкрутства у вигляді узагальненого параметра, що дозволить об'єднати як кількісні, так і якісні фактори банкрутства і подати результат у вигляді нечіткого аналітичного вираження Y.

Сформуємо лінгвістичну змінну «Ймовірність банкрутства» 3 терм-множиною значень $\mathrm{D}=\{$ «уже низька», «низька», «середня», «висока», «дуже висока»\}. Тоді як сімейство функцій приналежності може виступати стандартний п'ятирівневий 01-класифікатор, де функції приналежності - трапецієподібні трикутні числа (рис. 1) [6]:

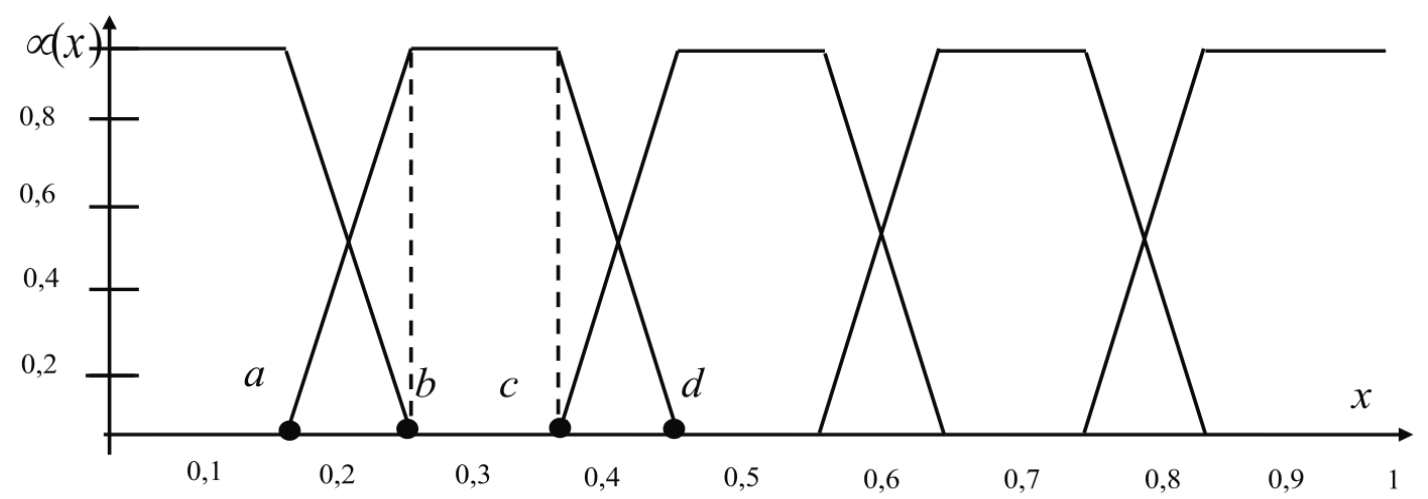

Рис. 1. Система трапецієподібних функцій приналежності на 01-носії

$$
\begin{aligned}
& \text { дуже низька: } \mu_{1}(x)=\left\{\begin{array}{c}
1,0 \leq x<0,15 \\
10(0,25-x), 0,15 \leq x<0,25 . \\
0,0,25 \leq x \leq 1
\end{array}\right. \\
& \text { низька: } \mu_{2}(x)=\left\{\begin{array}{c}
0,0 \leq x<0,15 \\
10(x-0,25), 0,5 \leq x<0,25 \\
1,0,25 \leq x<0,35 . \\
10(0,45-x), 0,35 \leq x<0,45 \\
0,0.45 \leq x \leq 1
\end{array}\right. \\
& \text { середня: } \mu_{3}(x)=\left\{\begin{array}{c}
0,0 \leq x<0,35 \\
10(x-0,35), 0,35 \leq x<0,45 \\
1,0.45 \leq x<0.55 \\
10(0,65-x), 0,55 \leq x<0,65 \\
0,0,65 \leq x \leq 1
\end{array}\right. \\
& \text { висока: } \mu_{4}(x)=\left\{\begin{array}{c}
10(x-0,55), 0,55 \leq x<0,65 \\
1,0,65 \leq x<0,75 \\
10(0,85-x), 0,75 \leq x<0,85 \\
0,0,85 \leq x \leq 1
\end{array}\right. \\
& \text { дуже висока: } \mu_{5}(x)=\left\{\begin{array}{c}
0,0 \leq x<0,75 \\
10(x-0,75), 0,75 \leq x<0,85 \\
1,0,85 \leq x \leq 1
\end{array}\right.
\end{aligned}
$$

Коли кожному фактору банкрутсва (F1... FN) відомі лінгвістичні оцінки D = (D1... DN), а також визначено систему ваг Фішберна $\mathrm{P}=(\mathrm{p} 1 \ldots \mathrm{pN})$ на основі системи переваг, тоді показник Y характеризується своєю лінгвістичної оцінкою, яка визначається функцією приналежності на 01-носії х:

$$
\mu(\mathrm{x})=\sum_{i=1}^{N} \mu_{i}(x) \times p_{i}
$$

де: 


$$
\mu_{\iota}(x)=\left\{\begin{array}{c}
(1), \text { якщо } L_{i}=\text { дуже низька } \\
\text { (2), якщо } L_{i}=\text { низька } \\
\text { (3), якщо } L_{i}=\text { середня } \\
\text { (4), якщо } L_{i}=\text { висока } \\
(5), \text { якщо } L_{i}=\text { дуже висока }
\end{array}\right.
$$

Серед факторів, які слід ураховувати в розрахунку комплексного показника ймовірності банкрутства, виокремимо наступні: базовий показник ймовірності банкрутства (Fбаз), фактор протиправних дій $(F n d)$, фактор «конфлікт інтересів» $(F \kappa i)$, фактор «розподіл корпоративних прав» $(F \kappa n)$ та фактор «галузеві та ринкові особливості» (Fzp). Вищезазначені показники дають можливість розрахувати ймовірність банкрутства корпоративних підприємств на основі регулярної річної інформації емітентів будь-якої галузі та враховують як якісні, так і кількісні показники діяльності корпоративних підприємств.

Ваги факторів, як правило, розраховуються за допомогою методу простого ранжування, пропорційного методу або методу попарного порівняння [2]. Якщо існує можливість проранжувати всі фактори в порядку спадання їх значущості, то значущість і-го фактора можна визначити за правилом Фішберна [10]:

$$
w_{i}=\frac{2(N-i+1)}{(N+1) N}
$$

Щоб визначити набір ваг Фішберна для змішаної системи уподобань, коли, поряд з перевагами, у систему входять відношення байдужості, необхідно визначати чисельники $r_{i}$ раціональних дробів за рекурсивною схемою:

$$
r_{i-1}=\left\{\begin{array}{c}
r_{i}, F_{i-1} \approx F_{i} \\
r_{i}+1, F_{i-1}>F_{i}
\end{array}, r_{N}=1, i=N . .2\right.
$$

У нашому випадку наявна змішана система уподобань, а саме - перевага надається базовому показнику ймовірності банкрутства (Fбаз), на другому місці знаходяться решта факторів: фактор

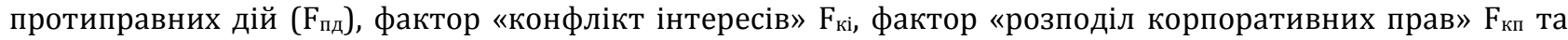
фактор «галузеві та ринкові особливості» $\mathrm{F}_{\text {гр. }}$.

Система співвідношень матиме вигляд:

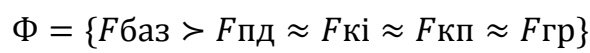

Співвідношення (7) - це OWA-оператор Ягера, причому, оскільки функції приналежності (8) мають трапецієподібну форму, то і лінійна суперпозиція (7) є трапецієподібним нечітким числом (що легко доводиться при використанні сегментного правила обчислень [7]). I можна звести операції 3 функціями належності до операцій з їх вершинами.

Отриману функцію виду (7) необхідно лінгвістично розпізнати, щоб виробити судження про якісний рівень показника ймовірності банкрутсва Ү. Для цього необхідно співвіднести отриману функцію $\mu$ (х) і функції $\mu$ і (х) виду (2-6). Якщо:

$$
\begin{aligned}
& (\forall x \in[0,1]) \sup \min \left(\mu(x), \mu_{i}(x)\right)=0 \\
& (\forall x \in[0,1]) \sup \min \left(\mu(x), \mu_{i}(x)\right)=\mu_{i}(x)
\end{aligned}
$$

У всіх проміжних випадках необхідно задатися мірою розпізнавання рівня. Таким заходом може бути різновид норми Хеммінга v [8]. Нехай дано два трапецієподібних числа (a1, a2, a3, a4) i (b1, b2, b3, b4) на 01-носії. Тоді ступінь подібності $v$ двох таких чисел може бути визначений як

$$
0 \leq v=1-\max \left\{\left|a_{1}-b_{1}\right|,\left|a_{2}-b_{2}\right|,\left|a_{3}-b_{3}\right|,\left|a_{4}-b_{4}\right|\right\} \leq 1
$$

У результаті отримуємо функцію приналежності фактору Ү і лінгвістичну інтерпретацію рівня цього фактору, супровід ступенем схожості виду (14) [8].

Якщо зіставити лінгвістичні змінні «Рівень фактору» і «Ступінь ризику банкрутства підприємства», то можна встановити деяку однозначну відповідність, наведену у табл. 1:

Таблиця 1. Шкала нечітких значень Y 


\begin{tabular}{|c|c|c|}
\hline Терм-множина & Назва & Характеристика \\
\hline $0-0,25$ & «Дуже низька» & $\begin{array}{l}\text { Прибуткова діяльність. У цьому випадку бізнес забезпечує генерацію } \\
\text { грошових потоків у розмірі, достатньому для відшкодування поточних } \\
\text { витрат (з урахуванням податкових відрахувань, які також можна віднести } \\
\text { до поточних витрат), а також отримання чистого економічного прибутку. }\end{array}$ \\
\hline $0,15-0,45$ & «Низька» & $\begin{array}{l}\text { Прибуткова діяльність. У цьому випадку бізнес забезпечує } \\
\text { генерацію грошових потоків у розмірі, достатньому для } \\
\text { відшкодування поточних витрат (з урахуванням податкових } \\
\text { відрахувань, які також можна віднести до поточних витрат), а також } \\
\text { отримання чистого нормального прибутку. } \\
\text { Або: } \\
\text { Беззбиткова діяльність. Грошові потоки, що формуються бізнесом, } \\
\text { покривають тільки поточні витрати, а генерація чистого прибутку не } \\
\text { здійснюється. }\end{array}$ \\
\hline $0,35-0,65$ & «Середня» & $\begin{array}{l}\text { 3биткова діяльність. На цій стадії грошові потоки, що генеруються } \\
\text { бізнесом, недостатні для покриття поточних витрат. Однак завдяки } \\
\text { накопиченим за попередні періоди ліквідним активам } \\
\text { забезпечується покриття всіх поточних витрат. }\end{array}$ \\
\hline $0,55-0,85$ & «Висока» & $\begin{array}{l}\text { Tuмчасова неплатоспроможність. Ця стадія характеризуєтся тим, } \\
\text { що ефективність генерації бізнесом грошових потоків слабка до } \\
\text { такої міри, що як накопичених раніше ліквідних активів, так і } \\
\text { поточного грошового потоку недостатньо для покриття поточних } \\
\text { витрат. Водночас є неліквідні активи, яких достатньо для } \\
\text { задоволення вимог усіх кредиторів. Але потрібен певний час для їх } \\
\text { трансформації в ліквідну форму і задоволення вимог кредиторів. } \\
\text { Aбо: } \\
\text { Гостра неплатоспроможність. Грошових потоків, що } \\
\text { генеруються бізнесом, недостатньо, а відсутність ліквідних активів } \\
\text { підприємства може бути подолана тільки якісною зміною бізнесу, } \\
\text { для чого потрібно більше часу, ніж при трансформації неліквідних } \\
\text { активів уліквідну форму. }\end{array}$ \\
\hline $0,75-1,0$ & «Дуже висока» & $\begin{array}{l}\text { Хронічна неплатоспроможність. У цьому випадку генерація } \\
\text { бізнесом грошових потоків настільки слабка, що навіть при якісній } \\
\text { зміні бізнесу грошових коштів буде недостатньо для здійснення } \\
\text { поточних платежів (свідомо збиткова діяльність). }\end{array}$ \\
\hline
\end{tabular}

Очевидно, що оцінка Ү в умовах нечіткої вихідної інформації з використанням такої шкали буде репрезентована також у нечіткому вигляді, а обраний принцип ранжування шкали дозволяє порівнювати отримані результати з ймовірними характеристиками.

\section{Висновки та перспективи подальших розвідок}

Аналіз відомих моделей діагностики ймовірності банкрутства дозволив виявити значну їх невідповідність сучасним умовам економіки України. У роботі розкрито переваги і можливості теорії нечіткої логіки стосовно аналізу ймовірності банкрутства підприємств та обгрунтовано доцільність застосування зазначеного економіко-математичного апарату для аналізу фінансової стійкості та ймовірності банкрутства корпоративних підприємств. У результаті дослідження було виокремлено систему якісних та кількісних показників діяльності корпоративних підприємств, які дають можливість розрахувати ймовірність їх банкрутства на основі регулярної річної інформації. Запропоновано математичну модель оцінки ймовірності банкрутства у вигляді узагальненого параметра (інтегрального показника), що розраховується з використанням системи показників, та дозволяє подати результат у вигляді нечіткого аналітичного вираження. Отриманий інтегральний показник досить гнучкий та дозволяє врахувати відповідні ринкові і специфічні, якісні та кількісні фактори діяльності підприємства. У роботі розроблено систему критеріїв адекватності математичної моделі економічному стану об'єкта дослідження, що дозволить обгрунтувати достовірність отриманих результатів.

\section{Список літератури}

1. Разрешение неплатежеспособности / Ведение бизнеса 2017 [Электронный ресурс]. - Всемирный банк. - Режим доступа: http://russian. doingbusiness.org/methodology/resolving-insolvency

2. Рубцов, Б. Б. Современные фондовые рынки / Б. Б. Рубцов. - М.: Альпина Бизнес Букс, 2007. - 926 с. 
3. Львова, Н. А. Особенности финансового анализа в условиях неплатежеспособности / Н. А. Львова, М. С. Семенова // Финансовый мир. Вып. 5 / Под ред. В. В. Иванова и Е. А. Почиковской. - М.: Проспект, 2014. - С. 119-122.

4. Толпегина, O. А. Эволюция комплексного формирования финансовой диагностики в прогнозировании банкротства: синергетический подход / О. А. Толпегина, Н. А. Мохунь // Вестник Московского университета имени С. Ю. Витте. - Серия 1: Экономика и управление. - 2014. - № 2. C. $19-25$.

5. Зайченко, Ю. П. Анализ финансового состояния и прогнозирование риска банкротства корпораций в условиях неопределенности / Ю. П. Зайченко, Ови Нафас Агаи Аг Гамиш //International Journal "Information Models and Analyses". - Vol. 1 /- 2012. Pp. 336-348.

6. Заде, Л. А. Основы нового подхода к анализу сложных систем и процессов принятия решений / Л. А. Заде. - В кн.: Математика сегодня, - М.: Знание, 1974, с. 5-49.

7. Kaufmann, A. Introduction to Fuzzy Arithmetic: Theory and Applications / A. Kaufmann, M. Gupta. - Van Nostrand Reinhold, 1991.

8. Рыжов, А. П. Элементы теории нечетких множеств и измерения нечеткости / А. П. Рыжов. - М.: Диалог-МГУ, 1998.

9. Matviychuk, A. Bankruptcy prediction in transformational eco- nomy: discriminant and fuzzy logic approaches / Andriy Matviychuk // Fuzzy economic review. - 2010. - May. - Vol. XV. — No. 1. - P. 2138.

10. Карпець, О. С. Моделі оцінки фінансової стійкості підприємства: когнітивний підхід [Электронный ресурс] / О. С. Карпець, І. М. Чуйко, С. В. Мілевський // Бізнес Інформ. - 2012. - No3. - С. 54-58.

11. Карпова, Н. А. Применение методов нечеткой логики при оценке и прогнозировании финансовой устойчивости консолидированных групп компаний / Н. А. Карпова // НАУКОВЕДЕНИЕ. - Том 7. - No5. - 2015. - Режим доступу: http://naukovedenie.ru/PDF/199EVN515.pdf (доступ свободный). Загл. с экрана. Яз. рус., англ. DOI: 10.15862/199EVN515.

\section{References}

1. Razreshenie neplatezhesposobnosti. (2017). Vedenye byznesa 2017. Retrieved from: http://russian. doingbusiness.org/methodology/resolving-insolvency.

2. Rubtsov, B. B. (2007). Sovremennye fondovye rynki. Moscow: Al'pyna Byznes Buks.

3. L'vova, N. A. \& Semenova, M. S. (2014). Osobennosti finansovoho analiza v usloviyakh neplatezhesposobnosty. Finansovyy mir, 5, 119-122.

4. Tolpehyna, O. A. \& Mokhun', N. A. (2014). Evolyutsiyya kompleksnoho formirovaniya finansovoy diahnostiki v prohnozirovaniy bankrotstva: sinerheticheskiy podkhod. Vestnyk Moskovskoho unyversyteta imeny S. Yu. Vitte, 2, 19-25.

5. Zaychenko, Yu. P., Nafas, Ovy Ahay \& Hamysh, Ah (2012). Analyz finansovoho sostoyaniya i prohnozyrovanie riska bankrotstva korporatsii $\mathrm{v}$ usloviyakh neopredelennosti. Information Models and Analyses, 1, 336-348.

6. Zade, L. A. (1974). Osnovy novoho podkhoda $k$ analizu slozhnykh sistem i protsessov prinyatiya resheniy. Moscow: Znanie.

7. Kaufmann, A. \& Gupta, M. (1991). Introduction to Fuzzy Arithmetic: Theory and Applications.

8. Ryzhov, A. P. (1998). Elementy teorii nechetkikh mnozhestv i izmereniya nechetkosty. Moscow: Dyaloh-MHU.

9. Matviychuk, A. (2010). Bankruptcy prediction in transformational economy: discriminant and fuzzy logic approaches. Fuzzy economic review, XV(1), 21-38.

10. Karpets', O. S. Chuyko, I. M. \& Milevs'kyy, S. V. (2012). Modeli otsinky finansovoï stiykosti pidpryyemstva: kohnityvnyy pidkhid. Biznes Inform, 3, 54-58.

11. Karpova, N. A. (2015). Primenenie metodov nechetkoy lohiki pri otsenke i prohnozyrovanii finansovoy ustoychivosti konsolidirovannykh hrupp kompaniy. Naukovedenie, 7(5). Retrieved: http://naukovedenie.ru/PDF/199EVN515.pdf.

\section{Стаття надійшла до редакції 10.10.2017 р.}

